\title{
EVALUATION OF ANTI-ALZHEIMER ACTIVITY OF ALCOHOLIC EXTRACT OF COSTUS PICTUS D. DON LEAVES IN WISTAR ALBINO RATS
}

\author{
PASHA KHOOSHBU*, IMTIYAZ ANSARI
}

Department of Pharmacology, Oriental College of Pharmacy, Navi Mumbai, Maharashtra, India. Email: pashakhush786@gmail.com

Received: 13 November 2019, Revised and Accepted: 05 December 2019

ABSTRACT

Objective: The aim was to assess the effect of anti-Alzheimer's activity of the alcoholic extract of Costus pictus D. Don Leaves in Alzheimer induce Wistar albino rats.

Methods: In the present study, the efficacy of an Extract of Costus pictus D. Don (ECPDD) was evaluated against scopolamine-induced Alzheimer in the Wistar albino rat. Donepezil at a dose of $2.5 \mathrm{mg} / \mathrm{kg}$, ECPDD was given in rat at a dose of $100 \mathrm{mg} / \mathrm{kg}$ body weight, $150 \mathrm{mg} / \mathrm{kg}$ body weight, and $200 \mathrm{mg} / \mathrm{kg}$ body weight. Anti-Alzheimer activity was assessed by victimization novel object recognition test, elevated plus maze, and Y-maze. And by biochemical test like neurotransmitter esterase activity, catalase activity, malonyldialdehyd and glutathione assays.

Results: Results showed that extracts treatment prevents Alzheimer and increases the level of acetylcholine, catalase, glutathione peroxidase, and phytochemical studies identified the presence of flavonoid and alkaloid in the ECPDD.

Conclusion: According to the results, it was concluded that the leave of $C$. pictus D. Don has significant anti-Alzheimer activity due to the presence of potent antioxidants such as flavonoid and anticholinesterase enzyme present in alkaloids.

Keywords: Alzheimer diseases, Costus pictus D. Don, Acetylcholinesterase, Scopolamine, Neurofibrillary tangles, Extract of Costus pictus D. Don.

(C) 2020 The Authors. Published by Innovare Academic Sciences Pvt Ltd. This is an open access article under the CC BY license (http://creativecommons. org/licenses/by/4. 0/) DOI: http://dx.doi.org/10.22159/ajpcr.2020.v13i2.36337

\section{INTRODUCTION}

Alzheimer's disease (AD) was discovered in 1906 by Alois Alzheimer, a German brain scientist. The sickness was initially ascertained during a 51-year-old lady named Auguste D. Her family brought her to Dr. Alzheimer in 1901 once noticing changes in her temperament and behavior. Dr. Alzheimer represented Auguste as having associate degree aggressive variety of dementedness, manifesting in memory, language, and activity deficits [1]. There are two core kinds of diseases. Familial AD affects folks younger than 65, accounting for nearly 500,000 AD cases within the US alone. The rest of the AD cases occur in adults aged 65 and older and are classed as spasmodic [2]. $\mathrm{AD}$ caused by genetic and environmental factors. Symptoms of AD include difficulty with speech, agitation, confusion, difficulty in retaining new memory, and loss of ability to communicate $[3,4]$. The main changes that take place in the brain are neurofibrillary tangle and beta-amyloid deposition, $\beta$-amyloid is associate degree insoluble, cyanogenic peptide macromolecule of concerning 39-43 amino acids. $\beta$-amyloid accumulates into plaques into oligomers. These insoluble proteins clusters are found within the neural area of the brains of AD patients and block nerve cells [5]. The accumulation of neurofibrillary tangles (NFT) among neurons is because of hyperphosphorylated tau proteins. An abnormal number of additional phosphates are added to the tau protein, causing the tau proteins to release from the microtubules, inflicting the tau proteins to unharnessed from the microtubules. These hyperphosphorylated proteins bind with each other and type tangles among the cell, referred to as NFT [6]. Currently, there is no cure for $\mathrm{AD}$, the drugs currently used are tacrine hydrochloride (Cognex) and donepezil hydrochloride (Aricept), rivastigmine (exelon), and galantamine (reminyl) [7]. Many plants useful for the treatment of anti-Alzheimer's in Ayurvedic system of medicine have been tested for their anti-Alzheimer effect in experimental animals. In plant phytochemicals can shield hominid from variability of syndromes. Phytochemicals are non-nutritive plant mixtures, which ensure caring, medicinal, or illness defensive things. Plants produce these substances to safe themself; however, fresh examination determines that various phytochemicals can guard creatures besides syndromes. There are several phytochemicals in pods and sages and each mechanism contrarily [8]. In the modern years, pioneers are more fascinated to shrub beginning medications as they are greatly biocompatible with minor side effects than the human-made medications. The ordinary yield and class are not reasonable due to slow development degree, overexploitation, and environment demolition which are possibly the key drawbacks to see the ever-growing marketplace request. Additional, farming of these rough therapeutically significant plants lacks satisfactory illnessfree elite implanting resources due to great vulnerability of the crop for rhizome rot, leaf spot, and microbial wilt [9]. Costus pictus D. Don referred to as internal secretion plant or Painted Spiral Ginger. It is a category of the herb in Costaceae family native to the United Mexican States. Bhattacharya et al. (1972) confirmed that C. speciosus alkaloids possess anticholin activity in vitro and in vivo. Thus, C. pictus D. Don additionally possesses the anticholinesterase activity and they decrease the breakdown of acetylcholine so may help in treating Alzheimer diseases [10].

\section{METHODS}

\section{Plant description}

Leaf

The massive, smooth, simple kind, alternate organized, rectangularshaped, and green color leaves have light-weight purple undersides and unit spirally organized around stems, forming partaking, and bowed clumps arising from underground rootstocks.

Flower

The plant flowers are of beautiful orange color, are created among the warmth months. Flower petals are quite sweet and nutritious. The plant to boot bears fruit, but its type is unknown. 
Plant

It reaches to relating to two feet tall, with the tallest stems falling over and lying on the lowest. The plant grows in partially shade/partially sun and it wants generally wet, clay, and sand. Costus does not have a disadvantage with pests and illness [11].

\section{Growth}

The spiral flag grows in either full sun or partial shade. It desires fertile soil and is typically planted on the brink of the water. Propagation is by the division of the clumps, cuttings, or by separating the offsets. That sort below the flower heads. Mites and nematodes are typically a retardant, significantly on light-weight, sandy soil. The plant has no diseases that are of major concern [12]

\section{Chemical constituent}

Pictus leaves disclosed that it is wealthy in macromolecule, iron, and inhibitor elements such as antioxidant, $\alpha$-tocopherol, $\beta$ carotene, terpenoids, steroids, and flavonoids. It was disclosed in another study that ethanolic extract was found to contain the very best range such as carbohydrates, triterpenoids, proteins, alkaloids, tannins, saponins, and flavonoids. Flavonoid and phenolic resin compound encompasses a neuroprotective impact $[13,14]$

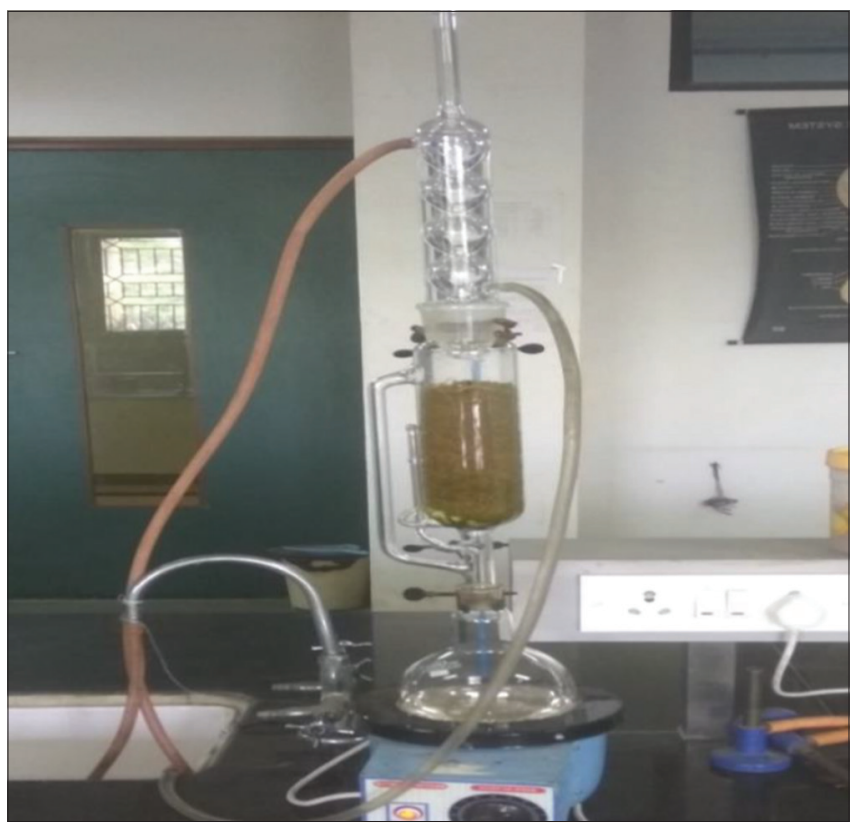

Fig. 1: Soxhlet apparatus

\section{Medicinal properties}

It possesses antimicrobial activity [15], hypoglycemic activity [16], anti-fertility activity [17], hyperlipidemic activity [18], ameliorative effect [19], diuretic effect [20], and putative activity [21].

\section{Toxicity}

The plant is usually eaten by animals that are additionally associate indicator to prove it's less cyanogenic. In the literature survey, it had been found that the ethanolic extract of $C$. pictus D. Don was safe [22,23]. $\mathrm{LD}_{50}$ of the ethanolic extract is according to be $2000 \mathrm{mg} / \mathrm{kg}$. Once literature surveys of varied analysis papers, the ultimate doses for the study 100,150 , and $250 \mathrm{mg} / \mathrm{kg}$ were selected [24].

\section{Plant material and extraction}

The plant (C. pictus D. Don) specimens for the proposed study were collected from the medicinal garden of Oriental College Of Pharmacy. A sample specimen voucher was submitted to Dr. Rajendra. D. Shinde, Director, Blatter Herbarium of St. Xavier's College, Mumbai. The leaves were washed with tap water and shade dried at normal room temperature with the aid of circulating airflow using fan. The continuous hot extraction methodology was used for getting plant extracts. The dried powder of $C$. pictus D. Don (150 g) was extract with $700 \mathrm{ml}$ of ethanol using Soxhlet apparatus. The collected extract is evaporated to remove the ethanol rotary vacuum evaporator. The dried herbal extract is mixed with carboxy methylcellulose (CMC) and administered to the animals.

\section{Animals}

Male albino Wistar rats weighing 250 g-386 g were used in this study. Animals were housed in plastic cages in seven groups. They had free access to food and water, and they were kept in a regulated environment $\left(23^{\circ} \mathrm{C}, 40-60\right.$ humidity). Experiments were carried out between 9:00 a.m. and 7:00 p.m., in an experimental room with in the animal facility. All animal procedures were conducted in strict under the rules of the ethical committee.

\section{Equipment and chemicals}

Electronic balance, elevated plus Maze, Y-maze, novel object apparatus, syringes, and needles, ethanol, CMC, and scopolamine. Donepezil tablet, 5,5'-dithiobis-(2-nitrobenzoic acid) (DTNB), acetylcholine, thiobarbituric acid (TBA). Nicotinamide adenine dinucleotide phosphate (NADP), and NADPH. Sodium bicarbonate glutathione reductase, and sodium azide.

\section{Preliminary phytochemical analysis [25]}

\section{Test for carbohydrate}

Molisch test

The test solution is combined with a small amount of Molisch's reagent ( $\alpha$-naphthol dissolved in ethanol) in a test tube. After mixing, a small amount of concentrated sulfuric acid is slowly added down the sides of the sloping test-tube, without mixing, to form a layer. A positive reaction is indicated by the appearance of a purple-red ring at the interface between the acid and test layers.

\section{Fehlings test}

In a test tube, add $2 \mathrm{ml}$ of the test solution and add equal volumes of Fehling A and Fehling B and place it in a boiling water bath for few minutes. When the content of the test tube comes to boiling, mix them together and observe any change in color or precipitate formation.

\section{Protein test}

Ninhydrin test: Ninhydrin is the most commonly used method to detect fingerprints, as the terminal amines or lysine residues in peptides and proteins sloughed off in fingerprints react with ninhydrin. To $3 \mathrm{ml}$ of the test solution add 3 drops of 5\% ninhydrine solution - boil over a water bath for 10 min purple bluish color appears.

\section{Steroid test}

Liebermann-Burchard test: The extracts were evaporated to dryness and the residues were extracted with petroleum ether and acetone. The insoluble residues left after extraction were dissolved in chloroform, and few drops of acetic anhydride were added along with a few drops of concentrated sulfuric acid from the side of the tube. The appearance of blue to blood red color indicates the presence of sterols in the extracts.

Glycoside test

Killer-kiliani test: $1 \mathrm{ml}$ of glacial acetic acid containing traces of $\mathrm{FeCl}_{3}$ and $1 \mathrm{ml}$ of concentrated $\mathrm{H}_{2} \mathrm{SO}_{4}$ were added to the extracts carefully. A reddish-brown color is formed at the junction of two-layer and the upper layer turns bluish-green in the presence of glycosides.

\section{Saponin test}

Foam test: The extract ( $2 \mathrm{~g}$ ) was shaken vigorously with $20 \mathrm{ml}$ of water and observed for persistent foam, which indicates the presence of saponins.

Test for flavonoids and phenol

Shinoda test: To the dry extract ( $2 \mathrm{~g}$ ), $5 \mathrm{ml}$ of ethanol ( $95 \% \mathrm{v} / \mathrm{v}), 5$ drops of hydrochloric acid, and $0.5 \mathrm{~g}$ of magnesium turnings were added. The appearance of pink-red purple color indicates the presence of flavonoids. 
Test for phenol

$0.50 \mathrm{~g}$ of phenol and $0.5 \mathrm{~g}$ of extract dissolved in $5 \mathrm{mi}$ of distilled water. Add a few drops of ferric chloride solution dark green color indicate the presence of phenol.

Test for tannins

Ferric chloride test: To $3 \mathrm{ml}$ of extract, $3 \mathrm{ml}$ of $5 \% \mathrm{w} / \mathrm{v}$ ferric chloride solution was added. The blue-black color indicates the presence of tannins.

Lead acetate solution

$2 \mathrm{ml}$ ethanolic extract of $C$. pictus D. Don leaves was treated with few drops of lead acetate solution. White precipitate indicates the presence of tannins.

Test for triterpenoids

Salkowski test: To the $2 \mathrm{ml}$ ethanol extract of C. pictus D. Don, $2 \mathrm{ml}$ chloroform and $2 \mathrm{ml}$ concentrated $\mathrm{H}_{2} \mathrm{SO}_{4}$ were added and shaken. The presence of red color in the chloroform layer and greenish-yellow fluorescence in the acid layer indicates the presence of steroids.

Test for alkaloids

Mayer's test: To $3 \mathrm{ml}$ of the filtrates, $1 \mathrm{ml}$ of Mayer's reagent (potassium mercuric iodide) was added. The appearance of a white precipitate indicates the presence of alkaloids.

Wagner's test: To $3 \mathrm{ml}$ of filtrate, $1 \mathrm{ml}$ of Wagner's reagent (iodine in potassium iodide) was added. The appearance of reddish-brown precipitate indicates the presence of alkaloids.

Hager's test: To $3 \mathrm{ml}$ of filtrate, $1 \mathrm{ml}$ of Hager's reagent (saturated picric acid solution) was added. The appearance of yellow precipitate indicates the presence of alkaloids.

\section{Experimental design}

Grouping of Animals: Animals were divided into seven groups, each of six animals.

- Group I: Control group oral administered by saline

- Group II: Intraperitoneal injection by scopolamine hydrochloride $(0.5 \mathrm{mg} / \mathrm{kg})$ (Negative control)

- Group III: Animal oral administered by donepezil tablet standard $(2.5 \mathrm{mg} / \mathrm{kg})$ and Alzheimer's induced with scopolamine

- Group IV: Animals oral administered by extract which is dissolved in CMC $(100 \mathrm{mg} / \mathrm{kg})$ and Alzheimer's induced with scopolamine

- Group V: Animals oral administered by extract which is dissolved in CMC $(150 \mathrm{mg} / \mathrm{kg})$ and Alzheimer's induced with scopolamine

- Group VI: Animals oral administered by extract which is dissolved in CMC $(250 \mathrm{mg} / \mathrm{kg})$ and Alzheimer's induced with scopolamine

- Group VII: Animals oral administered by extract which is dissolved in CMC $(250 \mathrm{mg} / \mathrm{kg})$

\section{Certificate}

This is to certify that the Research Proposal No: OCP/IAEC/2017-2018/03 dated 29/09/18. Entitled "Evaluation of antialzheimers activity of alcoholic extract of the leaves of Costus pictus.D.don in wistar albino rat of Thesis entitled- "EVALUATION OF NEUROPHARMACOLOGICAL ACTIVITY OF SELECTED PLANT" has been approved by the IAEC.

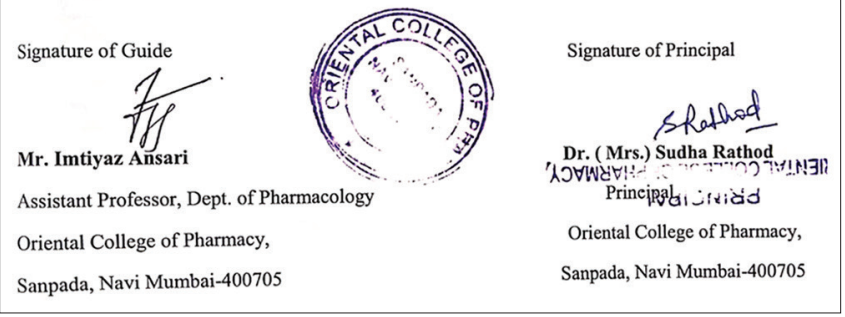

Fig. 2: Animal ethical approval certificate
Pharmacological studies

Induction of $A D$

Behavioral studies

AD mainly induced using scopolamine into the rat. Scopolamine, also known as levo-duboisine, and hyoscine, is an alkaloid drug with muscarinic antagonist effects. It is among the secondary metabolites of plants from Solanaceae (nightshade) family of plants. Scopolamine exerts its effects by acting as a competitive antagonist at muscarinic acetylcholine receptors, specifically $\mathrm{M}_{1}$ receptors. Scopolamine is used as a standard/reference drug for inducing amnesia in man and animals. The effects are generally interpreted as a cholinergic deficit and related to the hypothesis that acetylcholine is involved in memory functions. Scopolamine, besides influencing learning and memory, affects various types of behavior (e.g., locomotor activity, anxiety, and attention).

\section{Novel object recognition (NOR) test}

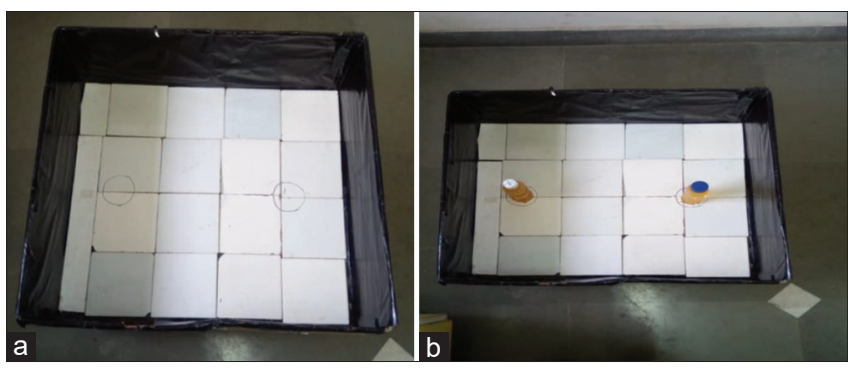

Fig. 3: Novel object recognition apparatus (a) habituation phase (b) retention phase

The NOR test is used to evaluate cognition, particularly recognition memory, in rodent models of central nervous system disorders. This test is based on the spontaneous tendency of rodents to spend more time exploring a novel object than a familiar one. The choice to explore the novel object reflects the use of learning and recognition memory.

Object recognition was performed in an exceedingly easy box, with or while not a clear wall. The procedure comprises three completely different parts: A habituation phase, an acquisition phase, and a retention part. On a primary day (habituation phase), rats were on an individual basis subject to one familiarization session of $10 \mathrm{~min}$, throughout that they will be introduced within the empty space, so as to become familiar with the equipment.

On an ordinal day (acquisition phase), animals were subjected to one 10-min session, throughout that floor-fixed two objects (A and B) placed in an exceeding rhombohedra position within the central line of the world. $10 \mathrm{~cm}$ from each other and $8 \mathrm{~cm}$ from the closest wall (each object occupies roughly $5 \mathrm{~cm}$ area by its size).

The two objects, manufactured from an equivalent material with the similar color and smell, were completely different in form however identical in size. Rats were allowed to explore the objects within the open field. The exploration time on every object is shown (as seconds) to point the exploring activity of rats.

On the $3^{\text {rd }}$ day (retention phase), rats are going to be allowed to explore the open field within the presence of two objects: The familiar object $\mathrm{A}$ and a completely unique object $\mathrm{C}$ in numerous shapes however in similar color and size (A and C). A recognition index (RI) (for retention session), calculated for each mouse, was expressed as the ratio RI = Time exploring novel object/(Time exploring novel object + Time exploring familiar object) $\times 100 \%[26]$.

\section{Elevated plus maze}

Elevated plus maze function the sensibility behavior model to gauge learning and memory in rodents. The procedure, technique, and finish purpose for testing, learning and memory are followed as per the parameters represented by the investigators operating within the space 
of neuropsychopharmacology. The equipment consists of two open arms and two boxed arms the arms area unit extended from a central platform and therefore the maze is elevated to a height of $25 \mathrm{~cm}$ from the ground. On the 14 day, every mouse was placed at the top of an open arm, facing far from the central platform. Transfer latency (TL) is that the time taken by mouse with all its four legs to maneuver into of the boxed arms that are recorded on the primary day, if the animal did not enter into the one of the enclosed arms within $90 \mathrm{~s}$, its gently pushed into one of the two enclosed arms and the TL will be assigned as $90 \mathrm{~s}$.

The mouse will be allowed to explore the maze for another $10 \mathrm{~s}$ and then returned to its home cage. Retention of this learned task will be examined $24 \mathrm{~h}$ after the $1^{\text {st }}$ day trail $\left(15^{\text {th }}\right.$ day). The inflexion ratio (IR) was calculated by the formula IR = Lo $-\mathrm{Lt} / \mathrm{Lo}$, where Lo is initial TL on $1^{\text {st }}$ day and Lt is TL after $24 \mathrm{~h}$. Decrease IR indicates the induction of amnesia, and increased IR indicates an improvement in cognition and memory impairment $[27,28]$.

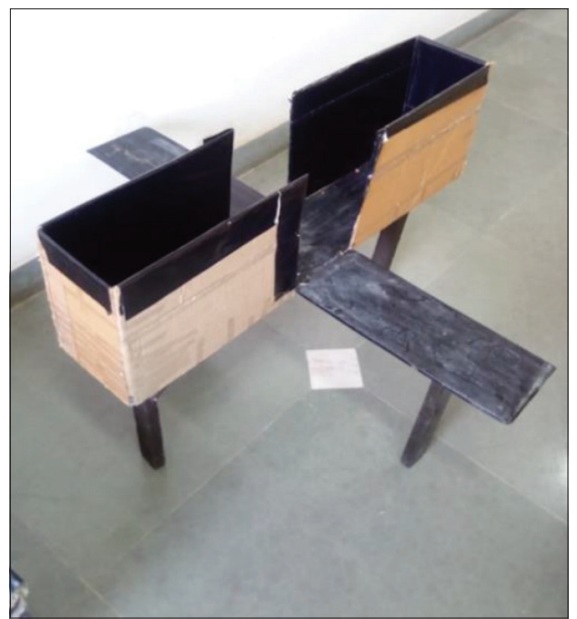

Fig. 4: Elevated plus maze apparatus

Y maze test

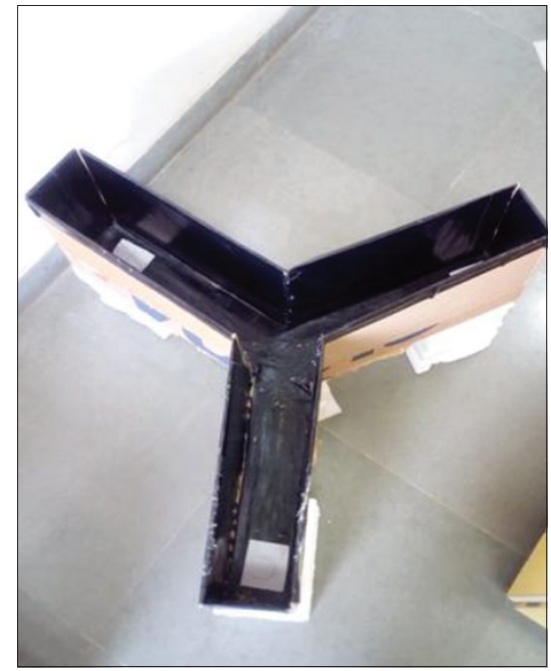

Fig. 5: Y maze apparatus

Y Maze spontaneous alternation could be an activity check for mensuration the disposition of rodents to explore new environments. Rodents generally opt to investigate a brand new arm of the maze instead of returning to one that was antecedent visited. Several components of the brain, including the hippocampus, septum, basal prosencephalon, and anterior cortex, are concerned during this task. Y-maze created of black painted wood. Every arm is $40 \mathrm{~cm}$ long, $12 \mathrm{~cm}$ height, $3 \mathrm{~cm}$ wide at an all-time low and $10 \mathrm{~cm}$ wide at the highest and converged in an equal triangular central space. Each mouse was placed at the tip of one arm associated allowed to maneuver freely through the maze throughout an eight min session. The flexibility to alternate needs that the mice understand that arm they need already visited. The series of arm entries, as well as attainable returns into an equivalent arm, were recorded visually. Immediate memory performance is going to be assessed by recording spontaneous alternation behavior. Entry was going to be thought of to be completed once the hind paws of the mouse had fully entered the arm. Alternation was outlined as consecutive entries into the three totally different arms (A, B, and C) on overlapping triplet sets. The share of trials within which all three arms were drawn, i.e., $\mathrm{ABC}, \mathrm{CAB}$, or $\mathrm{BCA}$ however not $\mathrm{BAB}$, was recorded as associate in nursing alternations' to estimate remembering. On the $19^{\text {th }}$ day, 90 min when the treatment of last dose arm entries was recorded and share alteration are going to be calculated [29] \% Alteration $=($ No of alteration/total arm entry-2)*.

\section{Biochemical test}

\section{Preparation of brain sample}

After assessing the learning and memory paradigms in scopolamineinduced amnesia, rats from each group were euthanized using a carbon dioxide chamber; brains were removed quickly and placed in ice-cold saline. Frontal cortex, hippocampus, and septum (and any other regions of interest) were quickly dissected out on a Petri dish chilled on crushed ice. The tissues were weighed and homogenized in $0.1 \mathrm{M}$ phosphate buffer ( $\mathrm{pH}$ 8). The samples of mice brain homogenates were collected in a different test. The supernatant was used for enzymatic assays.

Estimation acetylcholinesterase enzyme levels in the brain

$0.4 \mathrm{ml}$ aliquot of the material was added to a cuvette containing a pair of $6 \mathrm{cc}$ phosphate buffer $(0.1 \mathrm{M}, \mathrm{pH} 8)$ and $100 \mu \mathrm{l}$ of DTNB. The contents of the cuvette were mixed completely by effervescent air, and absorbance is measured at $412 \mathrm{~nm}$ in a very photometer. Once absorbance reaches a stable price, it absolutely was recorded because of the basal reading. $20 \mu \mathrm{l}$ of substrate, i.e., acetylthiocholine were added and alter in absorbance was recorded. Amendment within the absorbance per minute was therefore determined [30].

$$
\mathrm{R}=5.74^{*} 10^{\wedge}-4 * \mathrm{~A} / \mathrm{CO}
$$

$\mathrm{R}=$ rate in moles of substrate hydrolyzed (min/g tissue)

$\mathrm{A}=$ change in absorbance $/ \mathrm{min}$

$\mathrm{CO}=$ original concentration of the tissue $(\mathrm{mg} / \mathrm{ml})$.

\section{Determination of catalase (cat) principle}

Catalase activity was measured by the strategy of Aebi 0.1 metric capacity unit of supernatant was accessorial to a cuvette containing 1.9 metric capacity unit of $50 \mathrm{~mm}$ phosphate buffer ( $\mathrm{pH}$ 7.0). The reaction was started by the addition of $1.0 \mathrm{ml}$ of freshly ready $30 \mathrm{~mm} \mathrm{H} \mathrm{H}_{2}$. The speed of decomposition of $\mathrm{H}_{2} \mathrm{O}_{2}$ was measured spectrophotometrically from changes in absorbance at $240 \mathrm{~nm}$. The activity of enzyme was expressed as units/mg macromolecule. The reaction happens now when the addition of $\mathrm{H}_{2} \mathrm{O}_{2}$. Solutions were mixed well and also the initial absorbance $\left(\mathrm{A}_{1}\right)$ was browse when $15 \mathrm{~s}\left(\mathrm{t}_{1}\right)$ and also the second absorbance $\left(\mathrm{A}_{2}\right)$ when $30 \mathrm{~s}\left(\mathrm{t}_{2}\right)$. The absorbance was browse at wavelength $240 \mathrm{~nm}$ [31].

$$
\operatorname{Cat}(\mathrm{U}) / 100 \mu \mathrm{l} \text { of sample }=\left\{(\mathrm{dy} / \mathrm{dx}) * 0.003 / 38.3956^{*} 10^{\wedge-6}\right\}
$$

$\mathrm{dy} / \mathrm{dx}=$ change in absorbance $/$ minute

$0.003 / 38.3956^{*} 10^{\wedge}-6=$ molar extinction coefficient of $\mathrm{H}_{2} \mathrm{O}_{2}$.

\section{Determination of malondialdehyde (MDA)}

Procedure MDA was measured in step with the strategy of Ohkawa et al. $1 \mathrm{ml}$ of suspension medium was taken from the tissue material in an exceeding tube. $0.5 \mathrm{ml}$ of trichloracetic acid (TCA) was further to that, followed by $0.5 \mathrm{ml} 8 \%$ of TBA chemical agent. The tubes were coated with tin foil and unbroken within the water bathtub for $30 \mathrm{~min}$ at $80^{\circ} \mathrm{C}$ when $30 \mathrm{~min}$ over the tubes were taken out and placed within the cold water for $30 \mathrm{~min}$. These tubes were centrifuged for $15 \mathrm{~min}$ at 3000 rate. The absorbance of the supernatant was taken at $540 \mathrm{~nm}$, at 
temperature against applicable blank answer $\left(1 \mathrm{cc} \mathrm{H}_{2} \mathrm{O}, 0.5 \mathrm{~cm}^{3}\right.$ of halfhour TCA, and $0.5 \mathrm{ml}$ of $0.8 \%$ TBA). MDA worth was expressed as $\mathrm{n}$ moles MDA/mg of supermolecule [32].

$\operatorname{MDA}=\left(A_{540} * 100 / 1.56\right) * V_{t} /$ weight of tissue $* 1000$

$\mathrm{V}_{\mathrm{t}}=$ total volume

\section{Glutathione peroxidase assay}

3-ml cuvette containing a pair of 2.0 of phosphate buffer $(75 \mathrm{mmol} / \mathrm{L}$, $\mathrm{PH}$ 7.0), $50 \mu \mathrm{l}$ of $(60 \mathrm{mmol} / \mathrm{L})$ glutathione enzyme resolution, $50 \mu \mathrm{L}$ of $(0.12 \mathrm{~mol} / \mathrm{L}) \mathrm{NaN} 3,0.1 \mathrm{ml}$ of $(0.15 \mathrm{mmol} / \mathrm{L}) \mathrm{Na} 2$ ethylenediaminetetraacetic acid, $100 \mu \mathrm{L}$ of (3.0 mmol/L) NADPH, and $100 \mu \mathrm{L}$ of tissue supernatant was additional. Water was additional to form a complete volume of $2.9 \mathrm{ml}$. The reaction was started by the addition of $100 \mu \mathrm{L}$ of $(7.5 \mathrm{mmol} / \mathrm{L}) \mathrm{H}_{2} \mathrm{O}_{2}$, and also the conversion of NADPH to NADP was monitored by a continuous recording of the change of absorbance at $340 \mathrm{~nm}$ at 1-min interval for $5 \mathrm{~min}$. Enzyme activity of GSHP was expressed in terms of mg of proteins [33]

Enzyme activity $(\mathrm{M} / \mathrm{min} / \mathrm{ml})=\left(\mathrm{A}_{340} / \mathrm{min} * \mathrm{~V}_{\mathrm{t}}\right) /(€) * \mathrm{~d} * \mathrm{~V}_{\mathrm{s}}$

$(€)=6.22 * 10^{6} \mathrm{M}^{-1 *} \mathrm{~cm}^{-1}$

$\mathrm{d}=1 \mathrm{~cm}$

$\mathrm{V}_{\mathrm{t}}=$ total volume

$\mathrm{V}_{\mathrm{s}}=$ sample volume

\section{Statistical analysis}

The data obtained from animal experiments were analyzed with InStat Software by GraphPad (version 3.10). It was expressed as mean \pm standard error of mean. For statistical analysis, the data were subjected to analysis of variance followed by Dunnett's t-test. Results were considered to be statistically significant at $p \leq 0.05$. Significance levels were as follows:

*indicates $\mathrm{p} \leq 0.5$ as significant

$* *$ indicates $\mathrm{p} \leq 0.01$ as highly significant

$* * *$ indicated $\mathrm{p} \leq 0.001$ as very significant

*is used to denote the comparison of standard and test groups with the toxicant control group. Experimental data obtained from all the animals in different groups, recorded, and tabulated on a broadsheet using MS Excel program, to prepare the graphs.

\section{RESULTS AND DISCUSSION}

Preliminary phytochemical investigation

Table 1: Preliminary phytochemical result

\begin{tabular}{llll}
\hline $\begin{array}{l}\text { S. } \\
\text { No. }\end{array}$ & Phytoconstituents & Test & $\begin{array}{l}\text { Ethanolic extract } \\
\text { of the leaves } \\
\text { Costus pictus }\end{array}$ \\
\hline 1. & Test for carbohydrate & $\begin{array}{l}\text { Molisch test } \\
\text { Fehling test }\end{array}$ & + \\
2. & Protein test & Ninhydrin test & + \\
3. & Steroid test & Liebermann-bur & + \\
& & chard test & \\
4. & Glycoside test & Killer-killiani test & + \\
5. & Saponin test & Foam test & + \\
6. & Test for flavonoids & Shinoda test & + \\
7. & Test for tannin & Ferric chloride test & - \\
8. & Test for triterpenoids & Salkowski test & + \\
9. & Test for alkaloids & Mayer's test & + \\
& & Wagner's test & + \\
& & Hagers test & + \\
\hline
\end{tabular}

The revealed results of the preliminary phytochemical screening of ethanolic extract of the whole plant of C. pictus D. Don. The results are shown in Table 1.
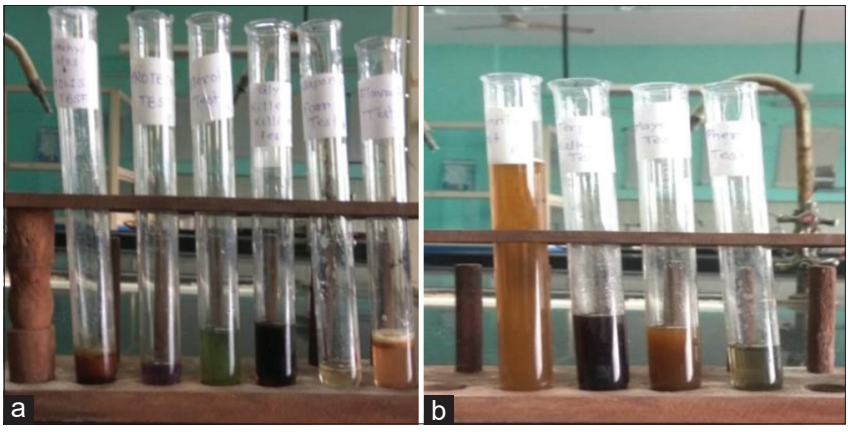

Fig. 6: (a-b) Qualitative phytochemical of Costus pictus D. Don

NOR test

The exploring time for novel objects expressed as RI. An increase in RI indicates anti-Alzheimer activity. From, Table 2, we are able to see that each one of the animals altogether the teams spent longer in exploring the novel object except the negative control (Scopolamine) group. The control group was $66.65 \pm .7 .881 \%$. Negative group showed a vital decrease in recognition $32.98 \pm 4.335 \%$. The upper dose showed vital $(p<0.01)$ increase within the novel object exploration indicate as increase RI as compared with an intermediate and lower group. The intermediate dose $(74.29 \pm 0.687 \%)$ and lower dose $(65.17 \pm 1.291 \%)$ showed a vital increase compared with the negative group. Conjointly, the extract only group $(75.93 \pm 1.695 \%)$ showed an increase in RI indicates as improvement of memory. The standard and treatment group antagonized the impact of scopolamine by increasing novel object exploring time.

Table 2: Effect of ECPDD on RI

\begin{tabular}{ll}
\hline Groups & RI \\
\hline Control group & $66.65 \pm 7.881$ \\
Negative control $(0.5 \mathrm{mg} / \mathrm{Kg})$ & $32.98 \pm 4.335$ \\
Standard $(2.5 \mathrm{mg} / \mathrm{kg})$ & $81.63 \pm 0.833$ \\
Low dose $(100 \mathrm{mg} / \mathrm{kg})$ & $65.17 \pm 1.291$ \\
Medium dose $(150 \mathrm{mg} / \mathrm{kg})$ & $74.29 \pm 0.687$ \\
High dose $(250 \mathrm{mg} / \mathrm{kg})$ & $80.83 \pm 1.681$ \\
Extract only $(250 \mathrm{mg} / \mathrm{kg})$ & $75.93 \pm 1.695$ \\
\hline
\end{tabular}

Values are expressed as the mean \pm standard error of mean of $n=6$ rats/treatment. Significance ${ }^{* *} \mathrm{p} \leq 0.01$. RI: Recognition index

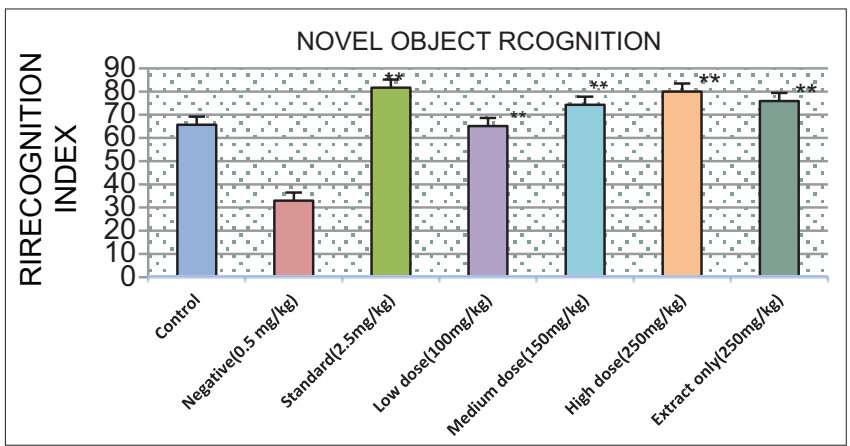

Fig. 7: Effect of ethanolic ECPDD leaves on recognition index

Elevated plus maze

Table 3: Effect of ethanolic ECPDD on IR

\begin{tabular}{llll}
\hline Groups & $\begin{array}{l}\text { TL } \\
\text { Day:14 }\end{array}$ & $\begin{array}{l}\text { TL } \\
\text { Day:15 }\end{array}$ & IR \\
\hline Control group & 15.833 & 6.5 & $0.594 \pm 0.079$ \\
Negative control $(0.5 \mathrm{mg} / \mathrm{kg})$ & 37.66 & 26.83 & $0.480 \pm 0.117$ \\
Standard $(2.5 \mathrm{mg} / \mathrm{kg})$ & 25.33 & 11.33 & $0.698 \pm 0.089$ \\
Low dose $(100 \mathrm{mg} / \mathrm{kg})$ & 26.66 & 15.3 & $0.512 \pm 0.056$ \\
Medium dose $(150 \mathrm{mg} / \mathrm{kg})$ & 23 & 12.33 & $0,530 \pm 0.134$ \\
High dose $(250 \mathrm{mg} / \mathrm{kg})$ & 27 & 9.833 & $0.598 \pm 0.053$ \\
Extract only $(250 \mathrm{mg} / \mathrm{kg})$ & 30.833 & 9.33 & $0.654 \pm 0.071$ \\
\hline
\end{tabular}

Values are expressed as the mean \pm standard error of mean of $n=6$ rats/treatment. Significance ${ }^{* *} \mathrm{p} \leq 0.01$. TL: Transfer latency, IR: Inflexion ratio 


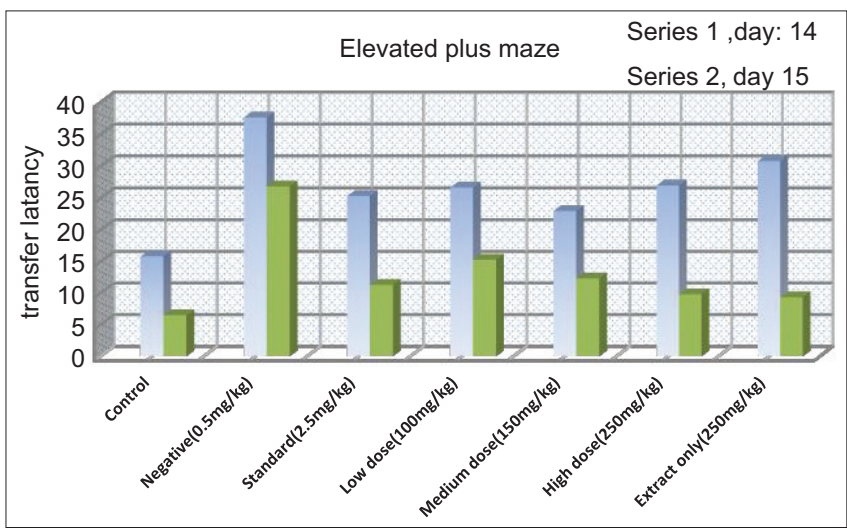

Fig. 8: Effect of ethanolic ECPDD on transfer latency

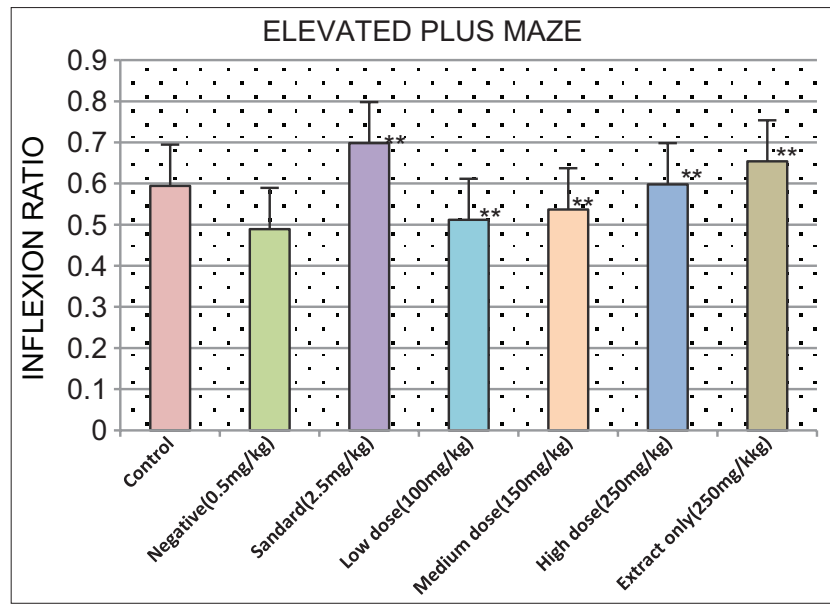

Fig. 9: Effect of ethanolic ECPDD on inflexion ratio

The impact of all the drug-treated groups was evaluated at the top of $14^{\text {th }}$ day. TL was recorded. It absolutely was seen that TL for all the drugtreated groups was less on the $15^{\text {th }}$ day as compared to the $14^{\text {th }}$ day. Decrease IR indicates the induction of a state of mind, and exaggerated IR indicates in improvement in psychological features and memory impairment. Negative control group (scopolamine) animals were considerably shrunken compared with all the groups that indicated that state of mind is evoked. Furthermore, high dose showed an increase in IR compared with intermediate and low dose separately and also the extract the only group showed significant increase compared with the negative group.

\section{Y MAZE}

Table 4: Effect of ethanolic ECPDD on \% alteration

\begin{tabular}{ll}
\hline Groups & Percentage alteration \\
\hline Control group & $51.38 \pm 1.338$ \\
Negative control $(0.5 \mathrm{mg} / \mathrm{kg})$ & $31.42 \pm 2.016$ \\
Standard $(2.5 \mathrm{mg} / \mathrm{kg})$ & $45.13 \pm 2.05$ \\
Low dose $(100 \mathrm{mg} / \mathrm{kg})$ & $41.75 \pm 0.705$ \\
Medium dose $(150 \mathrm{mg} / \mathrm{kg})$ & $44.5 \pm 1.361$ \\
High dose $(250 \mathrm{mg} / \mathrm{kg})$ & $47.5 \pm 0.530$ \\
Extract only $(250 \mathrm{mg} / \mathrm{kg})$ & $48.7 \pm 3.17$ \\
\hline
\end{tabular}

Values are expressed as the mean \pm standard error of mean of $n=6$ rats/treatment. Significance ${ }^{* *} \mathrm{p} \leq 0.01$

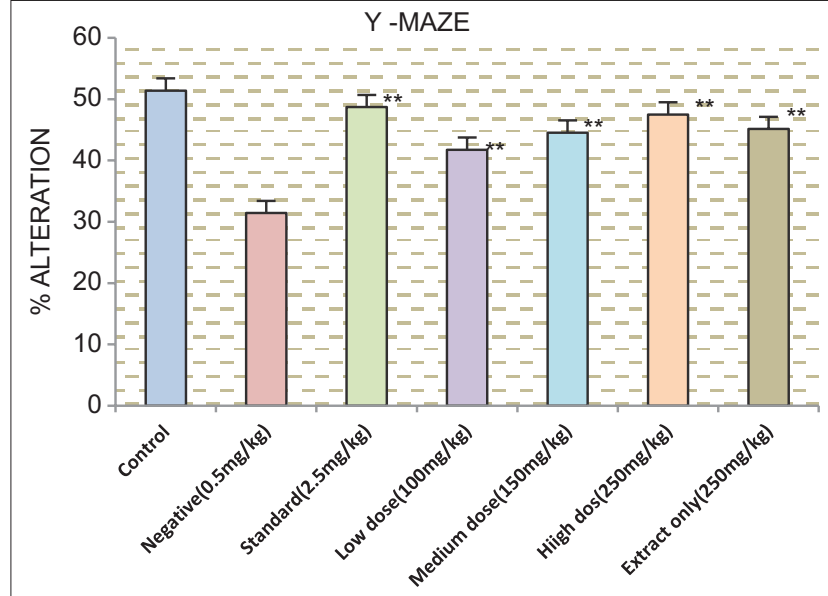

Fig. 10: Effect of ethanolic ECPDD on \% alteration

The percentage of alternation was reduced in the negative control group when compared with the control group animals considerably $(\mathrm{p}<0.001)$. Low, medium, and high dose animal treated with $(100,150$, and $250 \mathrm{mg} /$ $\mathrm{kg}$ ) and therefore the percentage of alternation was exaggerated in extract-treated group when put next with negative control group animals. The extract only group in which scopolamine is not present showed an increase in percentage alteration. Donepezil and CPDD showed an important exaggerated percent alternation that indicates protection from loss of remembering due to scopolamine induction and the decrease in percentage alternation indicates the decrease of remembering.

\section{Biochemical test}

Estimation of acetylcholinesterase enzyme levels in the brain

Table 5: Effect of ethanolic ECPDD on acetylcholine esterase level

\begin{tabular}{ll}
\hline Groups & Enzyme level \\
\hline Control group & $0.0711 \pm 0.001$ \\
Negative control $(0.5 \mathrm{mg} / \mathrm{kg})$ & $0.095 \pm 0.001$ \\
Standard $(2.5 \mathrm{mg} / \mathrm{kg})$ & $0.067 \pm 0.00115$ \\
Low dose $(100 \mathrm{mg} / \mathrm{kg})$ & $0.071 \pm 0.0025$ \\
Medium dose $(150 \mathrm{mg} / \mathrm{kg})$ & $0.068 \pm 0.0001$ \\
High dose $(250 \mathrm{mg} / \mathrm{kg})$ & $0.065 \pm 0.0005$ \\
Extract only $(250 \mathrm{mg} / \mathrm{kg})$ & $0.069 \pm 0.0013$ \\
\hline
\end{tabular}

Values are expressed as the mean \pm standard error of mean of $n=6$ rats/treatment. Significance ${ }^{* *} \mathrm{p} \leq 0.01$

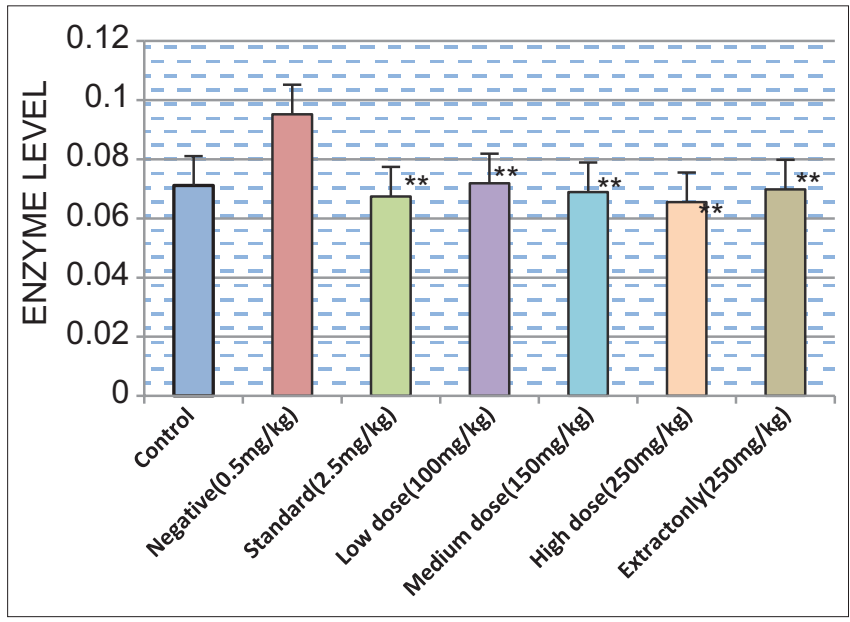

Fig. 11: Effect of ethanolic ECPDD on acetylcholine esterase level 
All the groups showed attenuate acetylcholinesterase accelerator activity as compared with hyoscine, as indicative in Table 5. The acetyl enzyme activity was considerably hyperbolic by hyoscine as compared to the control group. The rise in AChE activity by hyoscine was considerably reduced by drug-treated groups. High dose animals showed a vital decrease in acyl-enzyme activity compared with low and medium dose, whereas extract only group showed a vital decrease in acetylcholinesterase activity compared with medium and low. The decrease in a acetylcholinesterase enzyme activity showed improvement in memory and provides anti-Alzheimer's activity.

\section{Determination of catalase}

Table 6: Effect of ethanolic ECPDD on catalase activity

\begin{tabular}{ll}
\hline Groups & Catalase level \\
\hline Control group & $38.51 \pm 0.235$ \\
Negative control $(0.5 \mathrm{mg} / \mathrm{kg})$ & $33.3 \pm 0.500$ \\
Standard $(2.5 \mathrm{mg} / \mathrm{kg})$ & $40.50 \pm 0.115$ \\
Low dose $(100 \mathrm{mg} / \mathrm{kg})$ & $37.61 \pm 0.035$ \\
Medium dose $(150 \mathrm{mg} / \mathrm{kg})$ & $38.51 \pm 0.315$ \\
High dose $(250 \mathrm{mg} / \mathrm{kg})$ & $39.41 \pm 0.080$ \\
Extract only $(250 \mathrm{mg} / \mathrm{kg})$ & $38.79 \pm 0.040$ \\
\hline
\end{tabular}

Values are expressed as the mean \pm standard error of mean of $n=6$ rats/treatment. Significance ${ }^{* *} \mathrm{p} \leq 0.01$

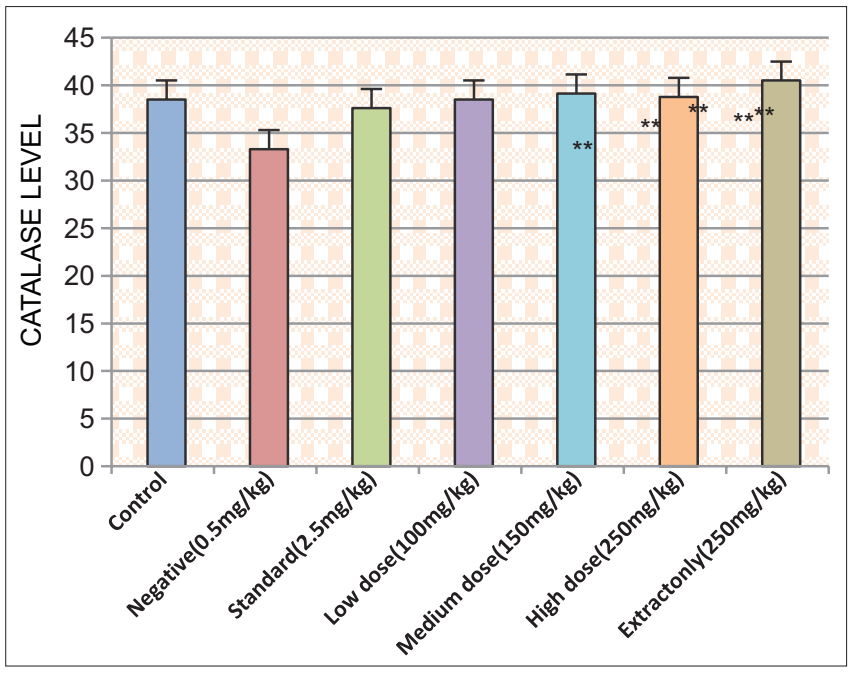

Fig. 12: Effect of ethanolic ECPDD on catalase activity

The enzyme level was reduced in the negative control group compared with the control group animals considerably $(\mathrm{p}<0.001)$. Low, medium, and high dose animal treated with $(100,150$, and $250 \mathrm{mg} / \mathrm{kg})$, the enzyme level was increased in ECPPD treated group compared with negative control group animals. The extract only group showed an increase in enzyme level. Donepezil and CPDD showed significantly increased enzyme level that indicates protection from oxidation and also the decreased enzyme level indicates the reaction of the neuronic cell.

\section{Determination of MDA level}

The MDA level of whole brain was markedly elevated once scopolamine treatment as compared with control. Within the treated groups there was a major $(\mathrm{p}<0.001)$ reduction in protein levels in $100 \mathrm{mg} / \mathrm{kg}, 150 \mathrm{mg} / \mathrm{kg}$, and $200 \mathrm{mg} / \mathrm{kg}$. Donepezil treated group showed important decrease in MDA levels. Results are shown in Table 7.
Table 7: Effect of ethanolic ECPDD on MDA level

\begin{tabular}{ll}
\hline Groups & MDA Level \\
\hline Control group & $0.0196 \pm 0.002$ \\
Negative control $(0.5 \mathrm{mg} / \mathrm{kg})$ & $0.031 \pm 0.0005$ \\
Standard $(2.5 \mathrm{mg} / \mathrm{kg})$ & $0.008 \pm 0.00025$ \\
Low dose $(100 \mathrm{mg} / \mathrm{kg})$ & $0.013 \pm 0.0006$ \\
Medium dose $(150 \mathrm{mg} / \mathrm{kg})$ & $0.011 \pm 0.000$ \\
High dose $(250 \mathrm{mg} / \mathrm{kg})$ & $0.004 \pm 0.0004$ \\
Extract only $(250 \mathrm{mg} / \mathrm{kg})$ & $0.011 \pm 0.00025$ \\
\hline
\end{tabular}

Values are expressed as the mean \pm standard error of mean of $n=6$ rats/treatment. Significance ${ }^{* *} \mathrm{p} \leq 0.01$

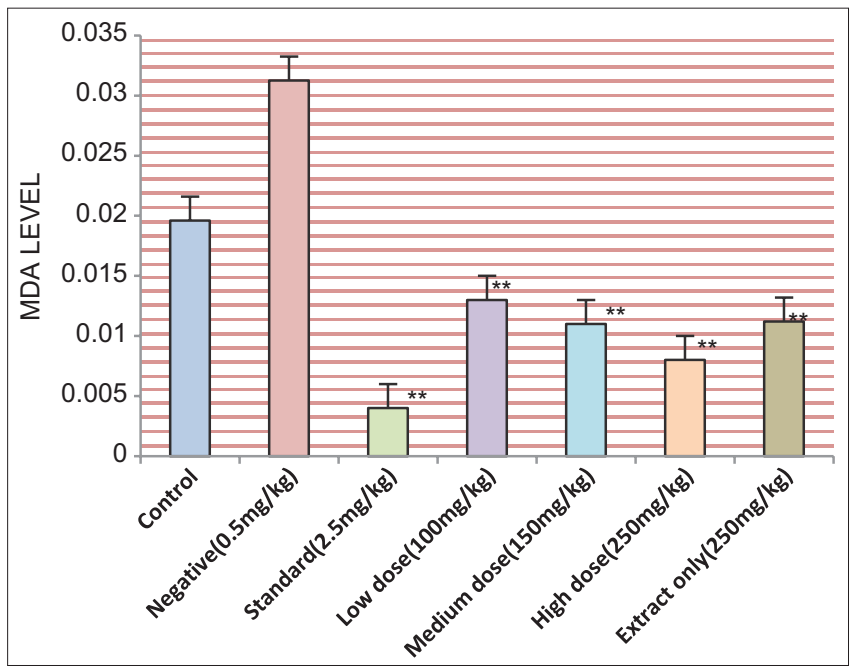

Fig. 13: Effect of ethanolic ECPDD on MDA

Determination of glutathione peroxidase

Table 8: Effect of ethanolic ECPDD on glutathione peroxides

\begin{tabular}{ll}
\hline Groups & GSH level \\
\hline Control group & $1.75 \pm 0.005$ \\
Negative control $(0.5 \mathrm{mg} / \mathrm{kg})$ & $1.475 \pm 0.005$ \\
Standard $(2.5 \mathrm{mg} / \mathrm{kg})$ & $2.249 \pm 0.031$ \\
Low dose $(100 \mathrm{mg} / \mathrm{kg})$ & $1.564 \pm 0.002$ \\
Medium dose $(150 \mathrm{mg} / \mathrm{kg})$ & $1.81 \pm 0.002$ \\
High dose $(250 \mathrm{mg} / \mathrm{kg})$ & $2.162 \pm 0.002$ \\
Extract only $(250 \mathrm{mg} / \mathrm{kg})$ & $2.090 \pm 0.00$ \\
\hline
\end{tabular}

Values are expressed as the mean \pm standard error of mean of $n=6$ rats/treatment. Significance ${ }^{* *} \mathrm{p} \leq 0.01$

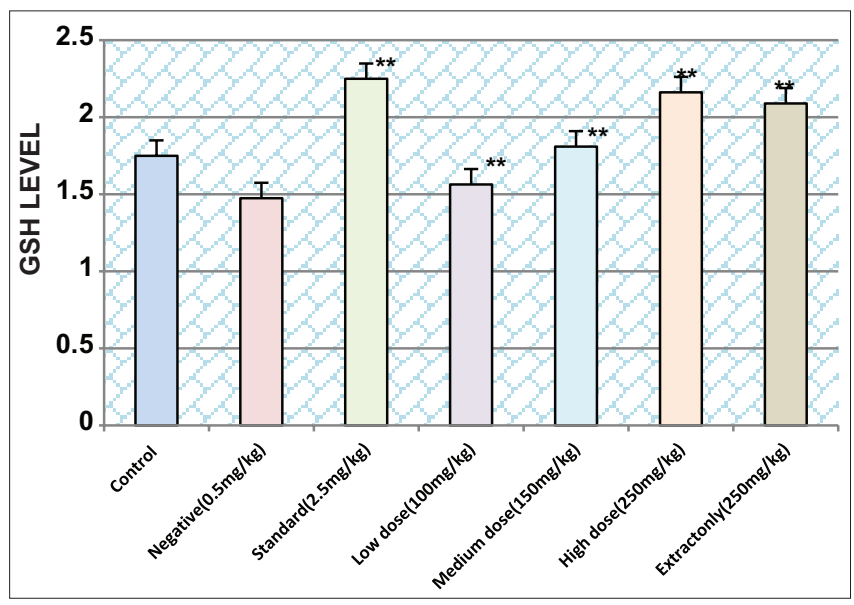

Fig. 14: Effect of ethanolic extract of Costus pictus D. Don leaves on glutathione Peroxides 
Glutathione plays a key role in maintaining correct perform and preventing aerophilous stress in human cells. It was act as a scavenger for chemical group radicals, singlet oxygen, and varied electrophiles. This narrows balance is maintained by glutathione reducates that catalyzes the reduction of GSSG to GSH. The decrease in the level of glutathione cause chemical reaction of the cell. The glutathione level within the brain markedly decreases in the negative group. Low, medium, and high doses treated with $(100,150$, and $200 \mathrm{mg} / \mathrm{kg})$ of CPDD showed considerably $(<0.01)$ increase in glutathione level. The standard group of animals showed markedly increase in glutathione level. The group within which scopolamine is not given additionally show an increase in glutathione level as compared to the control group.

\section{CONCLUSION}

From this study, it is clear that herbals play a key role against poor memory. Various herbal plants and plants extracts have significant memory improving activity in animal models. C. pictus D. Don have cholinesterase inhibitor property and useful anti-Alzheimer drug in delaying the onset and reducing the severity of $\mathrm{AD}$ when compared with that of reference drugs. The memory-improving activity is probably due to the presence of flavonoids. These memory-enhancing drugs showed that potential acting on cognitive functions by maintaining the acetylcholine level in the brain activity is of particular therapeutic importance. The ethanolic extract of $C$. pictus D. Don showed a significant increase in the onset of action and decrease in duration of action and recovery of time as compared to negative control thus justifying its antiAlzheimer activity which may be due to the presence of alkaloid and flavonoid as a phytoconstituent present.

\section{ACKNOWLEDGMENT}

We are grateful to our Principal Dr. (Mrs.) Sudha Rathod and Dr. (Mrs.) Vanita Kanse for their guidance and support as well as to the Pharmacology Department, Oriental College of Pharmacy, Navi Mumbai, Maharashtra, India.

\section{AUTHORS' CONTRIBUTION}

We declare that this work was done by the authors named in this article and all liabilities pertaining to claims relating to the content of this article will be borne by the authors. Miss Khooshbu Pasha collected the data and analyzed the data. Prof. Imtiyaz Ansari proof-read the whole manuscript, and suggested the necessary changes, and helped in designing the manuscript.

\section{CONFLICTS OF INTEREST}

The authors declare that there are no conflicts of interest regarding the publication of this paper.

\section{REFERENCES}

1. Khachaturian ZS, Radebaugh TS. Alzheimer's Disease: Cause(s), Diagnosis, Treatment, and Care. Boca Raton: CRC Press; 1996.

2. Alzheimer's Association; 2010. Available from: http://www.alz.org. [Last accessed on 2010 Oct 01].

3. Mayo Clinic Medical Information and Tools for Healthy Living. Mayo Foundation for Medical Education and Research; 2010. Available from: www.mayoclinic.org/diseases. [Last accessed on 2010 Nov 21].

4. Paolo G, Testa G, Gargiulo S, Starenghi E, Poli G, Leoarduzzi G. Oxidized cholesterol as the driving force behind the development of Alzheimer's disease. Front Aging Neurosci 2015;7:711-5.

5. Goran S, Leko MB, Wray S, Harrington C, Delalle I, Bazadona D, et al. Tau protein hyperphosphorylation and aggregation in Alzheimer's disease and other tauopathies, and possible neuroprotective strategies. Biomolecules 2016;6:6-20.

6. Goran S, Leko MB, Wray S, Harrington C, Delalle I, Bazadona D, et al. Tau protein hyperphosphorylation and aggregation in Alzheimer's disease and other tauopathies, and possible neuroprotective strategies. Biomolecules 2016;6:6-20.

7. Wolters Kluwer Health. Alzheimer disease drugs. In: Nursing Drug
Handbook. Philadelphia, PA: Wolters Kluwer Health; 2010. p. 546-51.

8. Pathak D, Alam K, Rohilla H, Rai AK. Phytochemical investigation of Boerhavia diffusa and Andrograph paniculata: A comparative study. Int J Pharm Pharm Sci 2012;4:250-1

9. Mohanty S, Parida R, Sandeep IS, Sahoo S, Nayak S. Evaluation of drug yielding potential of micropropagated Curcuma aromatica. Int J Pharm Pharm Sci 2015;7:511-4.

10. Shiny C. Thomas, phytochemical and pharmacological profiling of Costus pictus D. Don. a potenti antidiabetic plant. Pharmacogn Mag 2016:4:728-44.

11. Gupta H, Pandya K. Insulin plant: Review on photochemistry and pharmacology. Int J Infor Futurist Res 2018;5:9163-78.

12. Gilman EF. Florida: University of Florida. Costus igneus. Fact Sheet, No. FPS-151. EDIS-Electronic Data Information Source-UF/IFAS Extension, Inc.; 2012.

13. Devi VD, Urooj A. Nutrient profile and antioxidant components of Costus specious Sm. and Costus igneus Nak. Indian J Nat Prod Resour 2010;1:116-8.

14. Shankarappa L, Gopalakrishna B, Jagadish NR, Siddalingappa GS. Pharmacognostic and phytochemical analysis of Costus ignitius. Int Pharm Sci 2011;1:36-41

15. Ramya R, Dhamotharan R. Antibacterial activity and screening of antibacterial compounds of Costus pictus D. Don using GC-MS. Int J Sci Res 2016;5:8101-16.

16. Shiny CT, Saxena A, Gupta SP. Phytochemical and hypoglycaemic activity investigation of Costus pictus plants from Kerala and Tamil Nadu. Int J Pharm Sci Invent 2013;5:11-8.

17. Yasodha S, Arthi PN, Agarwal A. Antifertility activity of ethanolic extract of Costus pictus rhizome in female rats. Sch J Appl Med Sci 2017;5:62-4.

18. Chacko N, Shastry CS, Shetty P, Shyamma P, D'souza U, Maulika P. Anti hyperlipidemic activity of Costus igneus in triton X-100 induced hyperlipidemic rats. Int J Pharm Chem Sci 2012;1:813-8.

19. Sathuvan M, Vignesh A, Thangam R, Palani P, Rengasamy R, Murugesan K. In vitro antioxidant and anticancer potential of bark of Costus pictus D. Don. Asian Pac J Trop Biomed 2012;2:41-9.

20. Meléndez-Camargo ME, Castillo-Nájera R, Silva-Torres R, CamposAldrete ME. Evaluation of the diuretic effect of the aqueous extract of Costus pictus D. Don in rat. Proc West Pharmacol Soc 2006;49:72-4.

21. Manjula K, Pazhanichamy K, Kumaran S, Eevera T, Keefe CD, Rajendran K. Growth characterization of calcium oxalate monohydrate crystals influenced by Costus igneus aqueous stem extract. Int J Pharm Pharm Sci 2012;4:261-70.

22. Ozkan G, Sagdic O, Baydar NG, Baydar H. Antioxidant and antibacterial activities of Rosa damascena flower extracts. Food Sci Tech Int 2004;10:277-88.

23. Janarthanam B, Sumathi E. Antimicrobial activity of Gymnema sylvestre leaf and callus. J Trop Med Plants 2010;11:143-7.

24. Shirwaikar A, Rajendran K, Kumar CD, Bodla RG. Antidiabetic activity of aqueous leaf extract of Annona squamosa in streptozotocin nicotinamide Type 2 diabetic rats. J Ethnopharmacol 2004;91:171-5.

25. Aynehchi Y, Sormaghi MS, Amin G, Khoshkhow MK, Shabani A. Survey of Iranian plants for saponins, alkaloids, flavonoids and tannins. III. Int J Crude Drug Res 1985;23:33-41.

26. Alkam T, Kim HC, Hiramatsu M, Mamiya T, Aoyama Y, Nitta A, et al. Evaluation of emotional behaviors in young offspring of C57BL/6J mice after gestational and/or perinatal exposure to nicotine in six different time-windows. Behav Brain Res 2013;239:80-9.

27. Jaiswal AK, Bhattacharya SK. Effects of shilajit on memory, anxiety and brain monoamines in rats. Indian J Pharmacol 1992;24:12-7.

28. Jain NN, Ohal CC, Shroff SK, Bhutada RH, Somani RS, Kasture VS, et al. Clitoria ternatea and the CNS. Pharmacol Biochem Behav 2003;75:529-36.

29. Hughes RN. The value of Spontaneous Alternation Behavior (SAB) as a test of retention in Pharmacological investigations of memory. Neurosci Biobehav Rev 2004;5:497-505.

30. Ellman GL, Courtney KD, Anders U, Featherstone RM. A new and rapid colorimetric determination of acetyl cholinesterase activity. Biochem Pharmacol 1961;7:88-95.

31. Aebi H. Methods of Enzymatic Analysis. Vol. 2. New York: Academic Press; 1974. p. 674.

32. Khare P, Chaudhary S, Singh L, Yadav G, Verma S. Evaluation of nootropic activity of Cressa cretica in scopolamine induced memory impairment in mice. Int J Pharmacol Toxicol 2014;2:24-9.

33. Wood JL. In: Fishman WH, editor. Metabolic Conjugation and Metabolic Hydrolysis. Vol. 2. New York: Academic Press; 1970. p. 261-99. 